\title{
Gender imbalance in intensive care: High time for action and evaluation!
}

\author{
Caroline Hauw-Berlemont ${ }^{1}$, Charlotte Salmon Gandonnière ${ }^{2}$, Florence Boissier ${ }^{3,4}$, Nadia Aissaoui ${ }^{5}$, \\ Laetitia Bodet-Contentin ${ }^{6}$, Muriel Sarah Fartoukh ${ }^{7}$, Mercedes Jourdain ${ }^{8,9}$, Julien Le Marec ${ }^{10,11}$, \\ Fabienne Tamion ${ }^{12,13}$, Olfa Hamzaoui ${ }^{14}$ and Cécile Aubron ${ }^{15^{*}}$ (1) on behalf of the FEMMIR (Femme Médecins en \\ Médecine Intensive Réanimation) Group for the French Intensive Care Society
}

There is an accumulating evidence of persistent gender inequity in medicine including intensive care. In Science, the recognition of gender imbalance and the call for actions to redress it, has been reported since some years ago [1]. Unfortunately, the situation seems to last: recent literature in medicine has shown that women underrepresentation in leadership positions has not improved over the last 35 years [2-4]. Recent studies reported high rates of gender discrimination towards women intensivist with an impact on their professional and personal development $[4,5]$.

Assessing gender inequity is a key element of the policies fighting against women vertical segregation. However, awareness of the situation and willingness to change might not be sufficient for a real shift in our behaviors and for allowing gender equity in intensive care in the near future.

Specific actions as those listed recently by Vincent et al. [6] to improve gender balance have been proposed many times in numerous contexts [7]; however many authors report the lack of qualitative evaluable measures to determine whether changes have been implemented and have led to better gender equity.

It is urgent for our intensive care community to actively implement measurable actions and metrics to reach better equity but also to evaluate the impact of those actions

\footnotetext{
*Correspondence: cecile.aubron@chu-brest.fr; cecile.aubron@monash.edu

${ }^{15}$ Médecine Intensive Réanimation, Centre Hospitalier Régional et Universitaire de Brest, Université de Bretagne Occidentale, Brest, France Full list of author information is available at the end of the article
}

(Fig. 1). Words proved themselves insufficient. There will be no spontaneous transformation of what has been happening for ages and we want to warn on the urgent necessity to change the "standard of our behaviors."

Working groups to guarantee diversity and equity are crucial to assure identification, implementation and respect of measures to reach better gender balance. The French Intensive Care Society already created the FEMMIR (FEmmes Médecins en Médecine Intensive Réanimation) group in 2019 to promote women in intensive care.

Vranas et al. showed that a profound gender gap in critical care literature still exists in 2020 [8]. What obstacles can possibly be argued not to take measures in critical care publications to reverse the current trend?

As an example, critical care journals could trigger positive moves and take the lead by proposing the implementation of different measures that proved themselves efficient [9]:

- Journals can use quotas to improve gender balance within the editorial boards. Although quotas remain debated, considered unfair and inequitable by some, it must be understood that they are essential to succeed in achieving gender balance. Quota must not be considered as an outcome but as a tool to reach equity. Once the parity will be reached and sustained, this temporary measure will end.

- All peer review journals should annually publish percentages of women members in their editorial board, of women who have submitted/published a paper

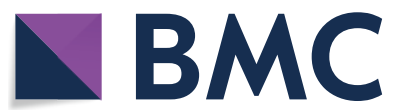

(c) The Author(s) 2021. Open Access This article is licensed under a Creative Commons Attribution 4.0 International License, which permits use, sharing, adaptation, distribution and reproduction in any medium or format, as long as you give appropriate credit to the original author(s) and the source, provide a link to the Creative Commons licence, and indicate if changes were made. The images or other third party material in this article are included in the article's Creative Commons licence, unless indicated otherwise in a credit line to the material. If material is not included in the article's Creative Commons licence and your intended use is not permitted by statutory regulation or exceeds the permitted use, you will need to obtain permission directly from the copyright holder. To view a copy of this licence, visit http://creativecommons.org/licenses/by/4.0/. The Creative Commons Public Domain Dedication waiver (http://creativeco mmons.org/publicdomain/zero/1.0/) applies to the data made available in this article, unless otherwise stated in a credit line to the data. 


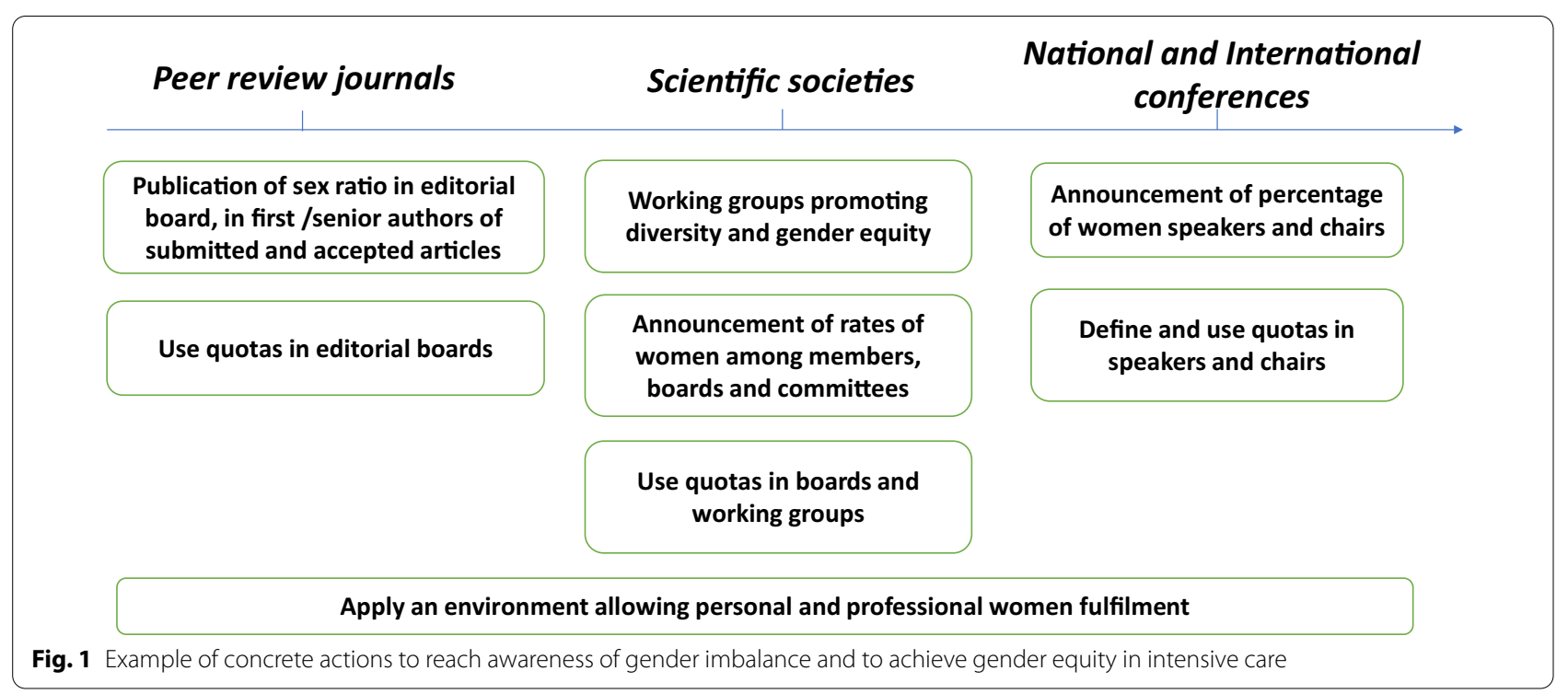

as a first or senior author and of women who have reviewed a submitted manuscript. Raising awareness on those numbers can lead to substantial changes.

- National and international conferences should announce the percentage of women speakers and chairs on their program.

- National and international societies of Intensive Care should also announce the rate of women among their members, their board and committees and adopt policies to reach gender balance and use quotas as well.

We think that a domino effect would follow and other measurable actions in favor of gender equity would emerge.

The improvement of numbers and balanced ratios could enable more profound changes, which would improve women doctors' sense of belonging and inclusion:

- Work conditions to allow personal and professional women fulfillment would change. Women might have specific needs including those related to maternity. Those measures include "breast-feeding or mother room" for women who breast-feed, childcare facilities for doctors and access to part time work. The "breast-feeding room" should be the norm in any University, Scientific Conference and learned scientific society. We also believe that allowing men to commit fully in their parenthood (especially through paternity leave extension) would improve quality of life at work for both genders and reduce discriminations related to maternity.
- Specific classes and courses about unconscious gender biases should be part of the youngest doctors' curriculum.

We are aware that the gender gap is rooted in profound and societal dynamics that need to be modified too. Educational differences between males and females happen at the youngest age [10] and strong and sustainable changes are required for a durable success of what the critical care community yearns for.

From now on, research to define the most effective measures and possible obstacles to their implementation and their efficacy is warranted.

We know that our intensive care community is highly responsive and aware of what is at stake here: the improvement of equity and gender diversity will make our specialty fairer and more attractive for future generations.

\section{Authors' contributions}

C HB, C SG, OH and CA drafted the manuscript. NA, LBC, MSF, MJ, JLM and FT amended the draft. All the authors read and approved the final manuscript.

\section{Funding \\ No funding}

Availability of data and materials Not applicable.

\section{Declarations}

Ethics approval and consent to participate Not applicable.

Consent for publication

Not applicable. 


\section{Competing interests}

The authors declare that they have no competing interests.

\section{Author details}

${ }^{1}$ Médecine Intensive Réanimation, Hôpital Européen Georges Pompidou, AP-HP, Université de Paris, Paris, France. ${ }^{2}$ Médecine Intensive Réanimation, INSERM CIC 1415, CRICS-TriGGERSep Network, CHRU de Tours, Tours, France. ${ }^{3}$ Médecine Intensive Réanimation, Hôpital Universitaire de Poitiers, Poitiers, France. ${ }^{4}$ INSERM CIC 1402 (ALIVE Group), Université de Poitiers, Poitiers, France. ${ }^{5}$ INSERM Unit 970, Cardiovascular Research Center (PARCC), Hôpital Européen Georges Pompidou, APHP, Université de Paris, Paris, France. ${ }^{6}$ Médecine Intensive Réanimation, INSERM CIC 1415, CRICS-TriGGERSep Network, CHRU de Tours and methodS in Patient-Centered Outcomes and Health ResEarch (SPHERE), INSERM UMR 1246, Université de Tours, Tours, France. ${ }^{7}$ Service de Médecine Intensive Réanimation, Faculté de Médecine Sorbonne, Université, Hôpital Tenon, APHP, Sorbonne Université, Paris, France. ${ }^{8}$ Médecine Intensive Et Réanimation - CHU de Lille, Lille, France. ${ }^{9}$ Membre de L'unité INSERM U1190 - Recherche Translationnelle Sur Le Diabète, Lille, France. ${ }^{10}$ Site Pitié-Salpêtrière Charles Foix, Service de Pneumologie, Médecine Intensive Réanimation, Département R3S, AP-HP Sorbonne Université, Paris, France. ${ }^{11}$ INSERM, UMRS1 158 Neurophysiologie Respiratoire Expérimentale Et Clinique, Sorbonne Université, Paris, France. ${ }^{12}$ Médecine Intensive Réanimation, Hôpital Universitaire de Rouen, Rouen, France. ${ }^{13}$ INSERM U1096 EnVi, Université Normandie, UNIROUEN, Rouen, France. ${ }^{14}$ Service de Réanimation Polyvalente, Hôpital Antoine Béclère, AP-HP, Université Paris-Saclay, Clamart, France. ${ }^{15}$ Médecine Intensive Réanimation, Centre Hospitalier Régional et Universitaire de Brest, Université de Bretagne Occidentale, Brest, France.

Received: 11 June 2021 Accepted: 25 June 2021

Published online: 07 July 2021

\section{References}

1. Gavaghan H. Making moves to redress the gender imbalance. Nature. 2000;405(6787):715-6. https://doi.org/10.1038/35015270 (PMID: 10864333).

2. Richter KP, Clark L, Wick JA, Cruvinel E, Durham D, Shaw P, Shih GH, Befort CA, Simari RD. Women physicians and promotion in academic medicine. N Engl J Med. 2020;383(22):2148-57.
3. Godier A, Nouette-Gaulain K, Cittanova ML, Beloeil H, Paugam-Burtz C, Lukaszewicz AC. Women in anaesthesia and intensive care medicine in France: Are we making any progress? Anaesth Crit Care Pain Med. 2020;39(4):507-11.

4. Hauw-Berlemont C, Aubron C, Aissaoui N, Bodet-Contentin L, Boissier F, Fartoukh MS, Jourdain M, Le Marec J, Pestel J, Salmon Gandonnière C, Tamion F, Hamzaoui O, FEMMIR Group for the SRLF Trial Group. Perceived inequity, professional and personal fulfillment by women intensivists in France. Ann Intensive Care. 2021:11(1):72. https://doi.org/10.1186/ S13613-021-00860-2 (PMID: 33978840; PMCID: PMC8116474).

5. Leigh JP, Grood C, Ahmed SB, Ulrich AC, Fiest KM, Straus SE, Stelfox HT. Toward gender equity in critical care medicine: a qualitative study of perceived drivers, implications, and strategies. Crit Care Med. 2019;47(4):e286-91. https://doi.org/10.1097/CCM.0000000000003625 (PMID: 30855331).

6. Vincent $J$, Juffermans NP, Burns KEA, et al. Addressing gender imbalance in intensive care. Crit Care. 2021;25:147. https://doi.org/10.1186/ s13054-021-03569-7.

7. Kang SK, Kaplan S. Working toward gender diversity and inclusion in medicine: myths and solutions. Lancet. 2019;393(10171):579-86. https:// doi.org/10.1016/S0140-6736(18)33138-6 (PMID: 30739693).

8. Vranas KC, Ouyang D, Lin AL, Slatore CG, Sullivan DR, Kerlin MP, et al. Gender differences in authorship of critical care literature. Am J Respir Crit Care Med. 2020;201:840-7.

9. Clark J, Horton R. What is The Lancet doing about gender and diversity? Lancet. 2019:393(10171):508-10. https://doi.org/10.1016/S0140-6736(19) 30289-2 (PMID: 30739674).

10. Bian L, Leslie SJ, Cimpian A. Gender stereotypes about intellectual ability emerge early and influence children's interests. Science. 2017;355(6323):389-91. https://doi.org/10.1126/science.aah6524 (PMID: 28126816)

\section{Publisher's Note}

Springer Nature remains neutral with regard to jurisdictional claims in published maps and institutional affiliations.
Ready to submit your research? Choose BMC and benefit from:

- fast, convenient online submission

- thorough peer review by experienced researchers in your field

- rapid publication on acceptance

- support for research data, including large and complex data types

- gold Open Access which fosters wider collaboration and increased citations

- maximum visibility for your research: over 100M website views per year

At BMC, research is always in progress.

Learn more biomedcentral.com/submissions 